\title{
MARKETING RESEARCH OF THE PHARMACEUTICAL MARKET OF MEDICINES USED TOPICALLY FOR DISEASES OF THE LOCOMOTOR APPARATUS
}

\author{
O.S.Shpychak, O.I.Tikhonov \\ National University of Pharmacy
}

Key words: assortment; pharmaceutical market; medicines used topically for diseases of the locomotor apparatus; dosage form

\begin{abstract}
The aim of this work is to carry out the marketing analysis of the assortment of medicines used topically for diseases of the locomotor apparatus presented at the pharmaceutical market of Ukraine for the subsequent substantiation of the composition and the type of a soft dosage form for a complex medicine, which is planned to application in sports medicine. It has been shown that the segment of medicines used topically for diseases of the locomotor apparatus consists of the products registered both as medicines and as dietary supplements. The medicines are registered in the group "M02A topical products for joint and muscular pain", the dietary supplements are presented in several groups. In general, the segment of the products investigated is provided by medicines in $\sim 89 \%$ and only in $\sim 11 \%$ by dietary supplements by the sales volume. In 2012 the group of the dietary supplements selected consisted of 313 trade names, at the same time the medicines are presented by 101 trade names. Both domestic and foreign producers are presented widely enough in the segment - the ratio between the volumes of supply is approximately permanent over all period of observations, although the participation of domestic producers, however, has the tendency to decrease in natural terms. The virtual group selected for analysis consists of such dosage forms as gels, ointments, creams, balsams, liniments and emulsions, solutions (alcoholic, oil, aqueous), applications and plasters, oils, sprays and extracts. The medicines produced in the form of gel were the leaders of sales according to the results of 2012, solutions and ointments occupied the second and third place, respectively. In the structure of the segment under research the soft dosage forms (except applications and plasters) occupy $68.28 \%$ in packs and $84.42 \%$ in money terms. In 2012 the segment of soft dosage forms (except applications and plasters) presented by 85 international nonproprietary names registered both as medicines and as dietary supplements. Fourteen substances provide $80 \%$ of sales in packs, and only 11 substances - in money terms. The undisputed leaders in the segment are diclofenac and ibuprofen - both in money equivalent and in packs - the first substance is presented by 17 international nonproprietary names, the second - by 4 ones. Thus, the marketing research of the market of medicines used topically for diseases of the locomotor apparatus has been carried out, and it has been shown that it is expedient to work in direction of creating soft dosage form, namely gel, for creation of a new complex medicine for treating microtraumas in sport medicine.
\end{abstract}

Athletic injuries of the locomotor apparatus were, are and always will be the widespread type of traumatic injuries, which not only influence on sportsmen achievements, but also worsen the quality of their life in whole [4, $8,11,13,14,19]$. Especially it concerns the athletes of high qualification - athletic injuries, particularly, injuries of joints, exclude them from the training process and sporting contests for a long period or completely [10, 12, 15-17].

Currently, soft dosage forms in the form of liniments, ointments, creams, gels have been widely used in rehabilitation of injured joints $[9,18]$. They are the complex heterogeneous disperse systems, which quality, efficiency and safety depend on the type and composition of a base-carrier, disperse state of medicinal substances, expedience of application and correct choice of excipients, preservatives, conditions of production, storage, etc. Soft dosage forms are simple for application, can combine several active substances of different activity direction in the same dosage form, and also provide du- ration of the presence of active substances directly in the site of drug application, etc. [2,3].

The aim of this work is to carry out the marketing analysis of the assortment of medicines used topically for diseases of the locomotor apparatus presented at the pharmaceutical market of Ukraine for the subsequent substantiation of the composition and the type of a soft dosage form for a complex medicine, which is planned to application in sports medicine.

\section{Materials and Methods}

The object of our research was the information about the structure of the market of medicines used topically for diseases of the locomotor apparatus registered in Ukraine, as well as about their price (marketing) descriptions for 2005-2012. Graphic and logical methods are used.

\section{Results and Discussion}

The segment of medicines used topically for diseases of the locomotor apparatus consists of the products re- 


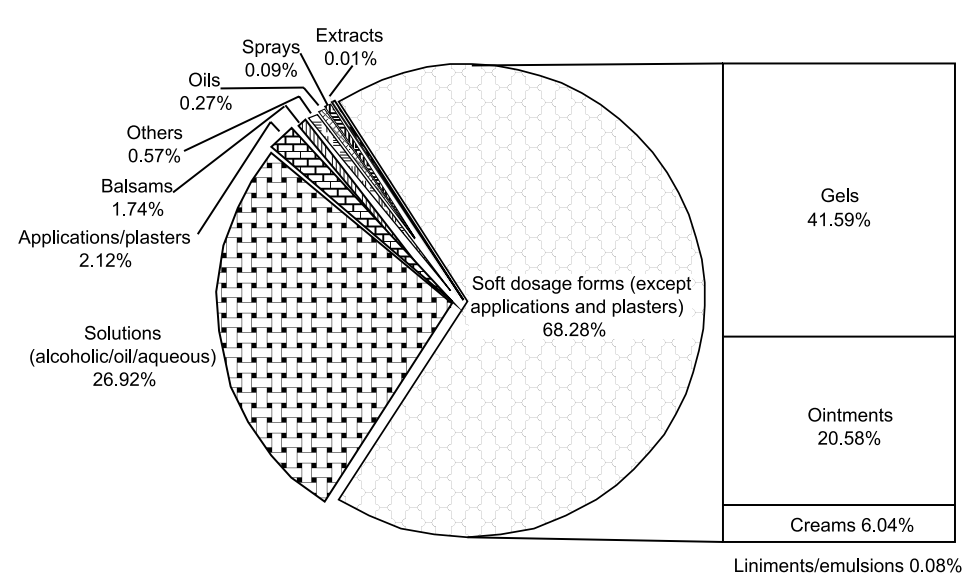

Fig. 1. The share distribution between different dosage forms in the virtual group (packs, 2012).

gistered both as medicines and as dietary supplements [5-7]. The medicines were presented according to the ATC-classification in the group " $\mathrm{M}$ - musculo-skeletal system", its capacity was $\sim 6 \%$ from the capacity of the pharmaceutical market of Ukraine in natural terms and $\sim 8 \%$ in money terms as of $2012[1,5-7]$. The dietary supplements were presented in the group "Y09 - supplements for treatment of diseases of the locomotor apparatus", as of 2012 its capacity was $\sim 3.5 \%$ and $\sim 4 \%$ in natural and money terms from the sales volume of dietary supplements in Ukraine, respectively. In turn, the segment is provided by medicines in $\sim 96 \%$ and only in $\sim 4 \%$ by dietary supplements $[1,5-7]$.

As for the current state of the pharmaceutical branch of Ukraine in the segment of products used topically for treating diseases of the locomotor apparatus, the medicines are registered directly in the group "M02A topical products for joint and muscular pain"; its capacity was $\sim 1.6 \%$ from the capacity of the pharmaceutical market of Ukraine in natural terms and $\sim 1.7 \%$ in money terms as of 2012 [1, 5-7]. The weighted average increase rate of the group for the period investigated has the tendency to decrease.

Dietary supplements are presented in several groups "Y09A2 - topical anti-inflammatory products", "Y09B1 products for treatment of contusions and injuries" and "Y09B2 - massage products". The capacity of the virtual group of dietary supplements consisting of products of three groups mentioned above and used topically for treatment of diseases of the locomotor apparatus was $\sim 2.8 \%$ and $\sim 2.6 \%$ in natural and money terms from the capacity of the pharmaceutical market of Ukraine as of 2012 [1, 5-7]. The weighted average increase rate of the virtual group of dietary supplements for the period investigated has also the tendency to decrease.

In general, the segment of the products investigated is provided by medicines in $\sim 89 \%$ and only in $\sim 11 \%$ by dietary supplements by the sales volume [1, 5-7]. It should be noted that over the last 7 years significant changes in sale distribution between the medicines for topical application in treating the locomotor apparatus and the dietary supplements used for the same purpose have not occurred. The insignificant increase of the share of the dietary supplements segment was observed in 2012 as compared to the beginning of the period under research in 2005.

In 2012 the group of the dietary supplements selected consisted of 313 trade names, at the same time the medicines are presented by 101 trade names [5-7].

The virtual group selected for analysis consists of such dosage forms as gels, ointments, creams, balsams, liniments and emulsions, solutions (alcoholic, oil, aqueous), applications and plasters, oils, sprays and extracts. The medicines produced in the form of gel were the leaders of sales acoording to the results of 2012, solutions and ointments occupied the second and third place, respectively. The negative dynamics was observed for such forms as ointments, balsams and liniments/emulsions; the situation was succeeded in improving for creams, applications/plasters and spray forms as compared with 2011.

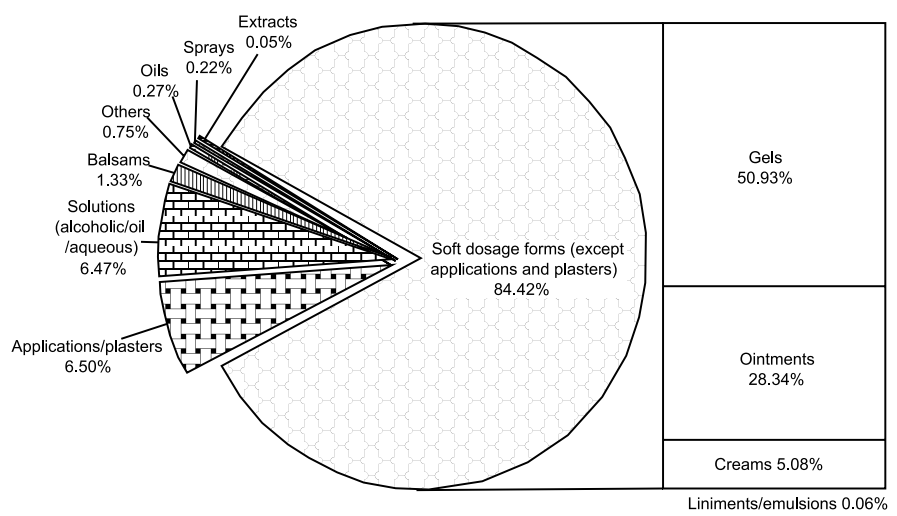

Fig. 2. The share distribution between different dosage forms in the virtual group (USA dollars, 2012). 


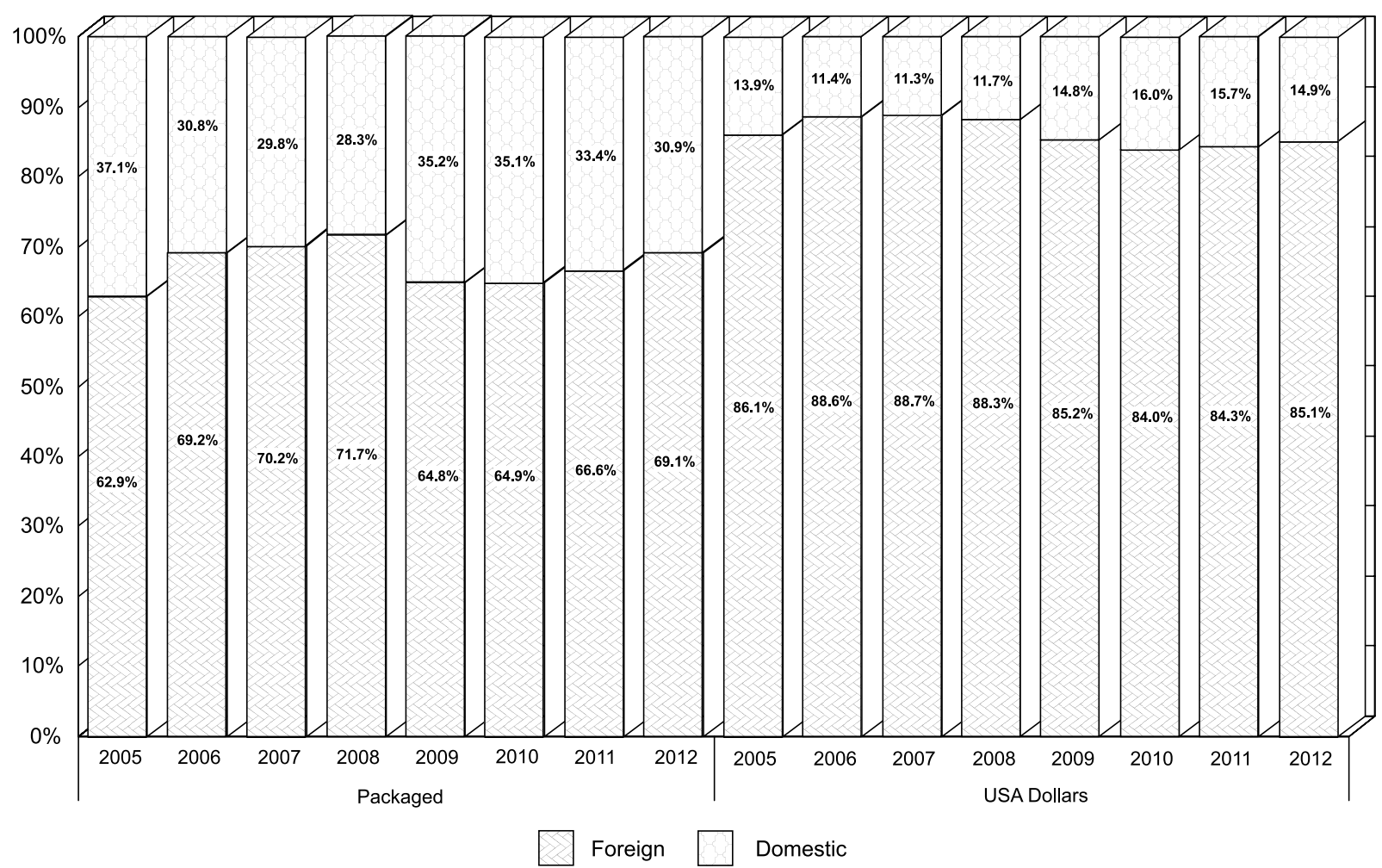

Fig. 3. Dynamics of the ratio of supply of domestic and foreign producers in the segment of soft dosage forms (except applications and plasters).

In the structure of the segment under research the soft dosage forms (except applications and plasters) occupy $68.28 \%$ in packs and $84.42 \%$ in money terms according to the results of 2012 (Fig. 1, 2); it indicates that they are the main forms used for topical treatment of diseases of the locomotor apparatus. In general, stagnation is observed in the share of the soft dosage forms segment among the products used topically for diseases of the locomotor apparatus.

Both domestic and foreign producers are presented widely enough in the segment. The results presented in Fig. 3 indicate that the ratio between the volumes of supply is approximately permanent over all period of observations, although the participation of domestic producers, however, has the tendency to decrease in natural terms.

In 2012 the segment of soft dosage forms (except applications and plasters) was provided by 85 international nonproprietary names (INN) presented both in the group of medicines and in the group of dietary supplements. Such substances as diclofenac $-22.79 \%$, ibuprofen $-8.67 \%$, ketoprofen $-7.67 \%$, comfrey $-7.37 \%$,

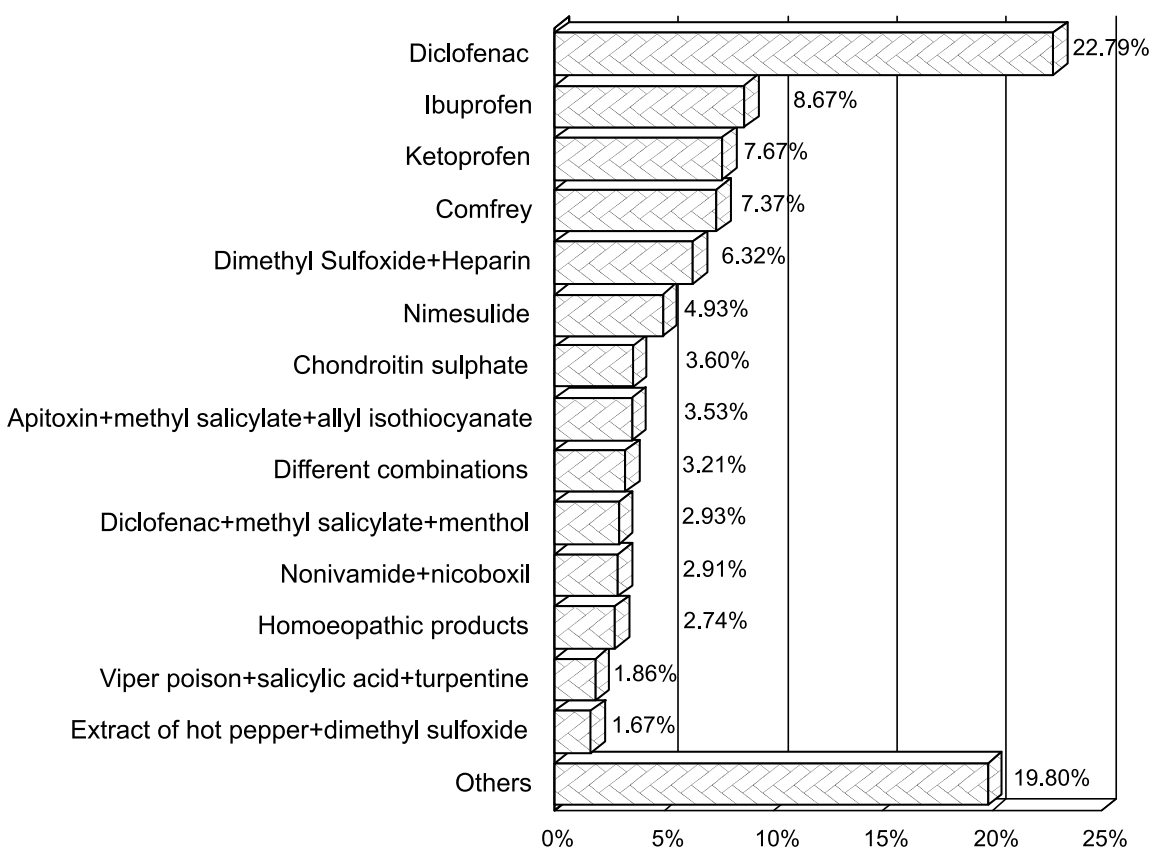

Fig. 4. TOP 80 of INN (sales in packs) in 2012 among soft dosage forms (except applications and plasters). 


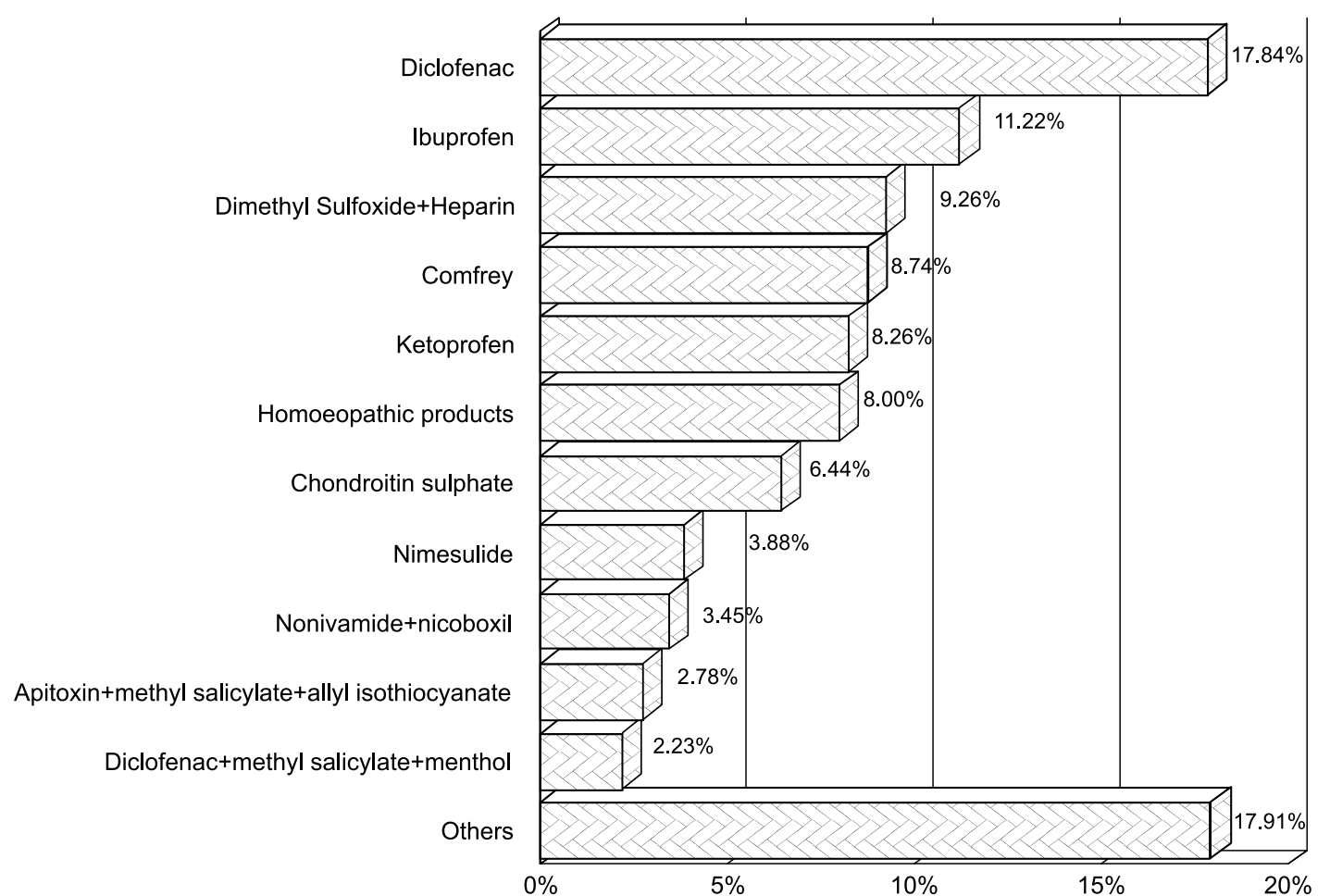

Fig. 5. TOP 80 of INN (sales in USA dollars) in 2012 among soft dosage forms (except applications and plasters).

dimethyl sulfoxide in combination with heparin $-6.32 \%$, nimesulide $-4.93 \%$, chondroitin sulphate $-3.60 \%$, combination of apitoxin with methyl salicylate and allyl isothiocyanate $-3.53 \%$, different combinations $-3.21 \%$, combination of diclofenac with methyl salicylate and menthol $-2.93 \%$, nonivamide with nicoboxil $-2.91 \%$, homoeopathic products $-2.74 \%$, combination of viper poison with salicylic acid and turpentine $-1.86 \%$ and the extract of hot pepper in combination with dimethyl sulfoxide $-1.67 \%$ (14 substances in all) provide $80 \%$ of sales in packs (Fig. 4).

Only 11 substances provide $80 \%$ of sales in money terms (Fig. 5): diclofenac - 17.84\%, ibuprofen $-11.22 \%$, combination of dimethyl sulfoxide with heparin and dexpanthenol $-9.26 \%$, comfrey $-8.74 \%$, ketoprofen $-8.26 \%$, homoeopathic products $-8.00 \%$, chondroitin sulphate $-6.44 \%$, nimesulide $-3.88 \%$, nonivamide in combination with nicoboxil $-3.45 \%$, combination of apitoxin with methyl salicylate and allyl isothiocyanate $-2.78 \%$, as well as combination of diclofenac with methyl salicylate and menthol $-2.23 \%$.

The leadership of diclofenac and ibuprofen - both in money equivalent and in packs - attracts the atten- tion; the first substance is presented by 17 international nonproprietary names, the second - by 4 ones [5-7].

Thus, it is expedient to work in direction of creating soft dosage form, namely gels, for creation of a new complex medicine for application in sport medicine.

\section{CONCLUSIONS}

1. The marketing research of the market of medicines used topically for diseases of the locomotor apparatus has been carried out.

2. It has been found that the quantitative and qualitative variety of medicines used topically for diseases of the locomotor apparatus is presented both by products of foreign firms and domestic producers.

3. It has been determined that the medicines produced in the form of gel are the leaders of sales - both in natural terms and in money equivalent.

4. It has been shown that in the structure of the segment under research the soft dosage forms (except applications and plasters) occupy $68.28 \%$ in packs and $84.42 \%$ in money terms; they are presented by 85 international nonproprietary names registered both as medicines and as dietary supplements. The undisputed leaders in the segment are diclofenac and ibuprofen.

\section{REFERENCES}

1. АТС-класифікаиія лікарських засобів [http://www.compendium.com.ua].

2. Баранова I.I. Теоретичне та експериментальне обгрунтування застосування сучасних гелеутворювачів природного та синтетичного походження у технології м'яких лікувально-косметичних засобів: дис. ... д. фарм. н. -X., 2011. - 308 c.

3. Білоус С.Б., Калинюк Т.Г., Гудзь Н.I. // Фармац. журн. - 2010. - №2. - С. 17-27.

4. Дембо А.Г. Актуальные проблемы современной спортивной медииины. - М.: Физкультура и спорт, 2003. -295 c.

5. Державний реєстр лікарських засобів Украӥни [http://www.drlz.kiev.ua]. 
6. Електронна версія Довідника лікарських засобів, яка містить перелік лікарських засобів, дозволених до застосування в Україні станом на 01.03. 2012 p. [http://www.pharma-center.kiev.ua/view/dov_lik_zas].

7. Компендиум 2012 - лекарственные препараты / Под ред. В.Н.Коваленко. - К.: МОРИОН, 2012. - 2320 с.

8. Левенецьь В.М. // Акт. проблеми фізкультури і спорту. - 2003. - №1. - C. 208-212.

9. Чичасова Н.В. // Фарматека. - 2004. - №7. - C. 66-69.

10. Behery O.M., Siston R.A., Harris J.D. et al. // Clin. J. of Sport Medicine. - 2014. - Vol. 24, №1. - P. 21-30.

11. Bourgois J.G., Boone J., Callewaert M. et al. // Sport Medicine. - 2014. - Vol. 44, №1. - P. 55-66.

12. Boykin R.E., Patterson D., Briggs K. K. et al. // Am. J. Sport. Med. - 2013. - Vol. 41, №10. - P. 2296-2301.

13. Dubois R.W., Melmed G.Y., Henning J. M. et al. // Aliment. Pharmacol. Ther. - 2004. - Vol. 19. - P. 197-208.

14. Edouardl P., Degache F., Oullion R. et al. // Int. J. Sport Medicine. - 2013. - Vol. 34, №7. - P. 654-660.

15. Giotis D., Zampeli F., Pappas E. et al. // Clin. J. of Sport Medicine. - 2013. - Vol. 23, №4. - P. $287-292$.

16. Joel B.H., Kevin J.C., Robert F.L. // Sports Health: A Multidisciplinary Approach. - 2014. - Vol. 6, №1. - P. 56-62.

17. Llewellyn T.M., Burdette G.T., Joyner A. B. et al. // Clin. J. of Sport Medicine. - 2014. - Vol. 24, №1. - P. 76-79.

18. Mackey A.L. // Scand. J. Med. Sci. Sports. - 2007. - Vol. 17, №6. - P. 613-614.

19. Owen A.L., Wong D.P., Dellal A. et al. // J. of Strength \& Conditioning Res. - 2013. - Vol. 27, №12. - P. $3275-3285$.

\section{МАРКЕТИНГОВІ ДОСЛІДЖЕННЯ ФАРМАЦЕВТИЧНОГО РИНКУ ПРЕПАРАТІВ, ЩО ВИКОРИСТОВУЮТЬСЯ МІСЦЕВО ПРИ ЗАХВОРЮВАННЯХ ОПОРНО-РУХОВОГО АПАРАТУ О.С.Шпичак, O.І.Тихонов}

Ключові слова: асортимент; фрармацевтичний ринок; лікарські засоби, що використовуються місцево при захворюваннях опорно-рухового апарату; лікарська фрорма Метою даної роботи було проведення маркетингового аналізу асортименту представлених на фрармацевтичному ринку України лікарських засобів, що використовуються місцево при захворюваннях опорно-рухового апарату, для подальшого обгрунтування складу та виду м'якої лікарської форми комплексного препарату, що планується до застосування в спортивній медицині. Показано, що сегмент засобів, які використовуються місцево при захворюваннях опорно-рухового апарату, складається з препаратів, зареєстрованих і як лікарські засоби, $i$ як дієтичні добавки. Лікарські засоби зареєстровані в групі «М02A - засоби для зовнішнього застосування при суглобовому та м'язовому болю», дієтичні добавки представлені в кількох групах. У иілому досліджуваний сегмент препаратів за обсягами реалізації на 89\% забезпечений лікарськими засобами та лише на 11\% дієтичними добавками. На 2012 рік група обраних дієтичних добавок складалась з 313 торгових найменувань, в той же час лікарські засоби представлені 101 торговою назвою. В сегменті досить широко представлені виробники як вітчизняного, так і закордонного походження - співвідношення між кількістю пропозиції приблизно незмінне на протязі всього періоду спостережень, хоча участь вітчизняних виробників все ж таки має тенденцію до зниження в натуральному вираженні. До складу обраної для аналізу віртуальної групи входять такі лікарські фрорми випуску: гелі, мазі, креми, бальзами, лініменти та емульсії, розчини (спиртові, олійні, водні), аплікації та пластирі, масла, спреї та екстракти. Лідерами реалізації за результатами 2012 року стали засоби, що випускаються в гелевій фрормі, друге та третє місце посіли розчини та мазі відповідно. У структурі досліджуваного сегменту м'які лікарські фрорми (окрім аплікацій та пластирів) займають, за результатами 2012 року, 68,28\% в упаковках та 84,42\% у грошовому вираженні. На 2012 рік сегмент м'яких лікарських форм (окрім аплікацій та пластирів) забезпечено 85 міжнародними непатентованими назвами, представленими і в групі лікарських засобів, і в групі дієтичних добавок; 80\% продажу в упаковках забезпечують 14 субстанцій, у грошовому вираженні всього 11 субстанцій. Беззаперечними лідерами в сегменті є диклофенак та ібупрофрен як у грошовому еквіваленті, так і в упаковках - першу речовину представлено 17 торговими найменуваннями, другу - 4. Таким чином, нами проведено маркетингове дослідження ринку лікарських засобів, що використовуються місцево при захворюваннях опорно-рухового апарату, та показано, що для створення нового комплексного препарату для лікування мікротравм у спортивній медицині доцільно працювати в напрямку створення м'якої лікарської форми, а саме гелю.

\section{МАРКЕТИНГОВЫЕ ИССЛЕДОВАНИЯ ФАРМАЦЕВТИЧЕСКОГО РЫНКА ПРЕПАРАТОВ, ИСПОЛЬЗУЕМЫХ МЕСТНО ПРИ ЗАБОЛЕВАНИЯХ ОПОРНО-ДВИГАТЕЛЬНОГО АППАРАТА О.С.Шпичак, А.И.Тихонов}

Ключевые слова: ассортимент; фармацевтический рынок; лекарственные средства, используемые местно при заболеваниях опорно-двигательного аппарата; лекарственная форма

Целью данной работы было проведение маркетингового анализа ассортимента представленных на фрармацевтическом рынке Украины лекарственных средств, используемых местно 
при заболеваниях опорно-двигательного аппарата, для дальнейшего обоснования состава и вида мягкой лекарственной формы комплексного препарата, планируемого к применению в спортивной медицине. Показано, что сегмент средств, используемых местно при заболеваниях опорно-двигательного аппарата, состоит из препаратов, зарегистрированных и как лекарственные средства, и как диетические добавки. Лекарственные средства зарегистрированы в группе «М02A - препараты для наружного применения при суставной и мышечной боли», диетические добавки представлены в нескольких группах. В целом исследуемый сегмент препаратов по объемам продаж на 89\% обеспечен лекарственными средствами и лишь на 11\% - диетическими добавками. На 2012 год группа выбранных диетических добавок состояла из 313 торговых наименований, в то же время лекарственные средства представлены 101 торговым названием. В сегменте достаточно широко представлены производители как отечественного, так и зарубежного происхождения - соотношение между количеством предложения практически неизменно в течение всего периода наблюдений, хотя участие отечественных производителей все же имеет тенденцию к снижению в натуральном выражении. В состав выбранной для анализа виртуальной группы входят такие лекарственные формы выпуска: гели, мази, кремы, бальзамы, линименты и эмульсии, растворы (спиртовые, масляные, водные), аппликации и пластыри, масла, спреи и экстракты. Лидерами реализации по результатам 2012 года стали средства, выпускаемые в гелевой форме, второе и третье место заняли растворы и мази соответственно. В структуре исследуемого сегмента мягкие лекарственные формы (кроме аппликаций и пластырей) занимают, по результатам 2012 года, 68,28\% в упаковках и 84,42\% в денежном выражении. На 2012 год сегмент мягких лекарственных форм (кроме аппликаций и пластырей) обеспечен 85 международными непатентованными названиями, представленными и в группе лекарственных средств, и в группе диетических добавок 80\% продаж в упаковках обеспечивают 14 субстанций, в денежном выражении - всего 11 субстанций. Бесспорными лидерами в сегменте являются диклофенак и ибупрофен как в денежном эквиваленте, так и в упаковках первое вещество представлено 17 торговыми наименованиями, второе - 4. Таким образом, нами проведено маркетинговое исследование рынка лекарственных средств, используемых местно при заболеваниях опорно-двигательного аппарата, и показано, что для создания нового комплексного препарата для лечения микротравм в спортивной медицине целесообразно работать в направлении создания мягкой лекарственной формы, а именно геля. 